\title{
An Evaluation of Impacts on Resource Levelling Practices and Performance by Construction Firms' in Kenya
}

\author{
Case Study of Insitu Concrete Works by Registered Construction Firms in Nairobi \\ County.
}

\author{
Absalom Habil Lamka ${ }^{1}$ \\ Department of Construction Economics \& Mgt, TUK, \\ Nairobi, Kenya.
}

\author{
Professor, Sylvester Munguti Masu² \\ Department of Construction Economics \& Mgt, TUK, \\ Nairobi, Kenya.
}

\author{
Dr. Githae Wanyona ${ }^{3}$ \\ Department of Construction Management, JKUAT, \\ Nairobi, Kenya.
}

\begin{abstract}
The construction industry is a highly dynamic sector and one of the most unique industries globally. It utilizes resources that have multiplier effect in the performance of any economy. In construction like in any other business, profitability fluctuates according to the efficient use of the resource input. Under performance by construction firms' has been a major issue in project delivery in Kenya. The problem of construction projects not being completed within the stipulated time, budgeted cost, quality specifications and judicious use of resources has remained un-resolved for construction firms. Poor planning and scheduling by construction firms has resulted in inefficient utilization of resources notably labour, plant, materials, finance and technology on construction sites. The purpose of the study was to evaluate the effectiveness of resource levelling practices on overall performance of construction firms' in Kenya.
\end{abstract}

In the study, key performance indicators (KPIs) were established objectively through a comprehensive literature search and a pilot study. The limitations of the suggested KPIs were discussed and a benchmark for measuring the performance of construction projects was set with a view of establishing a prioritized list of project performance evaluation for the construction firms in Kenya.

The study employed the mixed approach design. It used Stratified sampling technique for quantitative data collection and purposive sampling for qualitative interviews. The study targeted 143 participants from National Construction Authority (NCA) registered contractors The data analysis procedure adopted was: the descriptive statistics, correlation analysis, multiple regression analysis, statistical package for social sciences (SPSS) version 21 and Microsoft Excel 2010 software.

The findings from the study revealed three principal management tools that contribute towards the enhancement of construction firms' performance in Kenya namely: construction planning, financial control and resource control. It was found that these three management tools are associated with a number of key project characteristics, in particular, project cost, project time and quality Performance.
The result of this study is expected to ignite a paradigm shift for construction firms with respect to how prioritize construction planning and scheduling of resources during project implementation practice. Further, this paper has provided a prioritized list of relative importance for project performance evaluation which can be used by the top management in construction firms as a tool for enhancing construction project performance.

Keywords: Construction planning, resources, resource levelling, performance, fluctuations.

\section{INTRODUCTION}

\section{A. Background}

The construction industry is basically the sector involved with design, erection, repair and demolition of buildings and civil engineering works in the economy (Mbiti, 2008). According to Hillebrandt (2000), the sector contributes a sizeable portion of the Gross Domestic Product (GDP) nationally and globally. As documented in the Kenya National Bureau of Statistics (KNBS, 20i7), the construction industry in Kenya, for example, contributed $10.1 \%$, $4.9 \%$ and $4.1 \%$ towards the GDP of the country, in the years 2014, 2015 and 2016, respectively. This contribution is an average of $6.4 \%$, but is lower than the average contribution found in developed economies, which Hildebrandt (2000) observes to be $10 \%$.

Against this background, the statistics suggests the need for timely and realistic measures to be taken to improve the overall performance of the construction industry in Kenya. Ofori (2001) argues that a possible reason for the persistence of problems in the construction industry with regard to tackling wasteful utilization of resources, inefficiency and being late in delivery of projects in developing countries is the absence of project performance evaluation tools during project implementation. Therefore, the need to identify specific actions and good practices, which would help 
achieve desired results within the set time frame and budget is critical for projects performance (Gwaya, 2015

The construction industry utilizes resources which encompass labour, plant, materials, finance, time and space to deliver the constructed physical facilities to the clients. To meet the physical limits of construction resources, to avoid day-to-day fluctuation in resource demands and to maintain an even flow in application of construction resources, resource levelling would be required in the construction industry. In the words of Harington (2007), 'resource levelling is a management technique which attempts to minimize the fluctuation in requirements by optimizing the use of resources to project activities in a manner that will improve productivity and performance.

Undesirable resource fluctuation on construction sites are of a great concern to the parties in the construction industry as it affects the overall project performance and productivity levels (El-Rayes, 2009). High resource peak demand causes congestion problems on site as activities have to wait for the resources resulting in decline in performance of workers (Chitkara, 2012).

\section{B. Research Problem}

Ineffective evaluation of resource levelling management practices on performance of construction firms remains a problem to ponder over in the construction industry in Kenya. Lack of appropriate resource levelling management tools on performance evaluation by construction firms in Kenya has made planning of resources unpredictable and thereby influencing overall construction project performance (Gwaya, 2015). Advancement in complexity of construction projects has exerted formidable challenges in resources utilization as the resources need to be well managed in order to reduce the inherent uncertainty in balancing demand for resources with the available supply (PMI, 2015). Resources fluctuation beyond acceptable limits is bad for employee morale as it negatively affects crew efficiency, team spirit and leads to poor project performance. The network programming methods in existence are not responsive to the need of the field personnel as they are too dependent on specialists for implementation and don't depict resource utilization (Galloway, 2006). Despite the previous studies in Kenya on project performance and the application of existing resource utilization techniques notably by Talukhaba (1999), Gichunge (2000), Wanyona (2005),Masu (2006), Muchungu (2012) and Gwaya (2015) among others, the problem of fluctuation in resources on construction sites has remained un-resolved to contractors in their predictive resource levelling practices on resource idleness and resource mobilization.. The aforementioned researchers established that time and cost performance of projects in Kenya escalated to the extent that over $70 \%$ of the projects initiated were likely to extend in time with a magnitude of over $50 \%$, while over $50 \%$ of the projects were likely to increase in cost with a magnitude of over $20 \%$.

\section{Research objectives}

The main objective of the study was to evaluate the effectiveness of resource levelling management tools on performance with regard to resource utilization of construction firms' in Kenya. The case study of in-situ concrete works by construction firms' in Nairobi County was considered under the survey.

\section{Study Significance}

The findings from the study would be valuable in the construction industry as they will prioritize the effectiveness of resource levelling management tools on performance with regard to resource utilization. This would assist the construction firms to minimize undesirable resource fluctuation and improve performance in resource utilization practice in project delivery in Kenya. Further, the proposed resource levelling management tools for evaluation on performance with regard to resource utilization from the research will contribute to the existing body of knowledge, as well as improving decision making skills for top management and thereby contributing towards improved performance by construction firms

\section{RESOURCE UTILIZATION STUDIES}

\section{A. Introduction}

According to Chitkara (2012) the construction industry is a complex organization which centers' on the project under construction. He argues that the industry is unique in many ways as traditionally the design is quite divorced from construction. Resource requirements and organization of work differ with each task. The un-explored site geology, uncertain weather, unforeseen natural calamities, faulty designs and engineering failures such as ill-defined scope of work and lack of construction experience would affect performance. Muchungu (2012) reinforces the argument by stating that the rapid changing technology, fast moving economic conditions, susceptible environments and new dimensions to the complex nature of projects would pose challenges to resource utilization. Hence, effective management of resources to deliver the constructed facility to the client within the predetermined duration, budgeted cost and stipulated quality specifications is crucial for project performance and implementation.

\section{B. Resource demand schedules}

Schedules are key documents in the management of construction projects. A project schedule establishes the start date, duration, completion date, and resource needs for each activity in the project. Mistakes in the schedule may cause the project team to allocate resources to the wrong place at the wrong time or may prevent the parties from accurately assessing whether the project is ahead of or behind schedule (El-Rayes, 2009) Knowing precisely when an activity is going to begin also has substantial cost implications. Scheduling the construction process is essential not only so that projects can be completed profitably and on time, but also so that any delays can be evaluated in order to prove 
entitlement to time and cost compensation. As problems are encountered, the schedule helps project managers rearrange project tasks and resources so that they can meet the primary objectives of time, cost, and quality under limited resource and budget constraints.

\section{Resource allocation}

The Resource allocation has been defined by Chitkara (2012) as the process that breaks down work activities into the types and quantities of labour, equipment, materials, time and finance needed to perform the work. As a result, one is able to determine the resource needs and plan accordingly. ElRayes (2009) observed that each project will need a different blend of quality and quantity of resources to achieve specified performance objectives. Therefore, resource allocation would be used to provide a feasible schedule for the completion of the project within the management constraints. When there are insufficient resources available, the activities have to be rescheduled to free necessary resources. In the case where two activities require the same resources simultaneously and there are insufficient resources to start both activities as planned, the activity with the highest priority will get the scarce resource first.

\section{Resource levelling technique}

According to PMI (2015) resource levelling is a 'technique in which start and finish dates are adjusted based on resource constraints with the goal of balancing demand for resources with the available supply'. The technique ensures that resource demand does not exceed resource availability. There would be reallocation of total or free slack in activities to minimize fluctuation in the resource requirement profile while maintaining the original project completion time. As PMI (2015) goes on explain, 'resource levelling involves the delay of non-critical activities within their total float limits and manipulations of the daily resource requirements'. The thinking behind resource levelling is the establishment of schedules in which resources become as level as possible without changing the original completion time of the project, the aim being to reduce the peaks and troughs associated with resources requirements in a project (Chitkara, 2012).This would be more efficient because every upswing has a cost impact whether it comes from bringing new crew to the site of the project or procuring more equipment. The costs of learning on the job can be exorbitant as they arise from problems of logistics, teamwork and site safety issues.

\section{E. Performance measurement for resource levelling}

Choudhury (2002) and cited in Masu (2006) argues that a project will be considered totally successful if it gets completed within the stipulated contract period, original set budget and the set specifications or the standards of workmanship. On the other hand, a project may be considered a failure if it abandoned half-way or completed with a changed concept, does not a produce as specified in terms of quality of product and if it becomes sick soon after going into commercial production

\section{F. Tools for performance assessment on resource levelling}

Chitkara (2012) argues that projects have become much more complex and difficult to execute due to the increasing uncertainties in technology, scope of the work, project complexity, fluctuating resource flows and all sorts of external influence. Work study technique has been used quite often in the construction industry as an assessment tool in determining the success in productivity performance The two main work study techniques used in the construction industry for resource utilization are method study and work measurement. The method study technique is used to record work procedures, provide systems of analysis and develop improvements. Further the methodology can assist in project planning, site layout evaluation, balancing plant and other resources at the work place and re-planning of production (Harris, 2013). In the case of in-situ concrete, multi activity chart for example could be used in the balancing of resources

On the hand, work measurement is the measurement of the time required to perform a task so that at output standard of production for a worker and/ or plant may be established (expected) which may be compared with the actual production). In the case study of in-situ concrete, work measurement could be carried out by use of the following techniques; time study, activity sampling, synthesis and analytical estimating (Forster, 2014).

\section{G. Conceptual framework}

In order to improve performance of construction firms, there was need to evaluate and rank resource levelling management tools on performance with regard to resource utilization. Presented in figure 1 is the conceptual framework for the study showing how construction resource levelling practice (dependent variable) will be affected by six independent variables of construction project performance. The factors affecting resource levelling and construction project performance were obtained as noted by previous studies notably Gwaya (2015), PMI, (2015), Masu (2006), Gichunge (2000) and Talukhaba (1999).

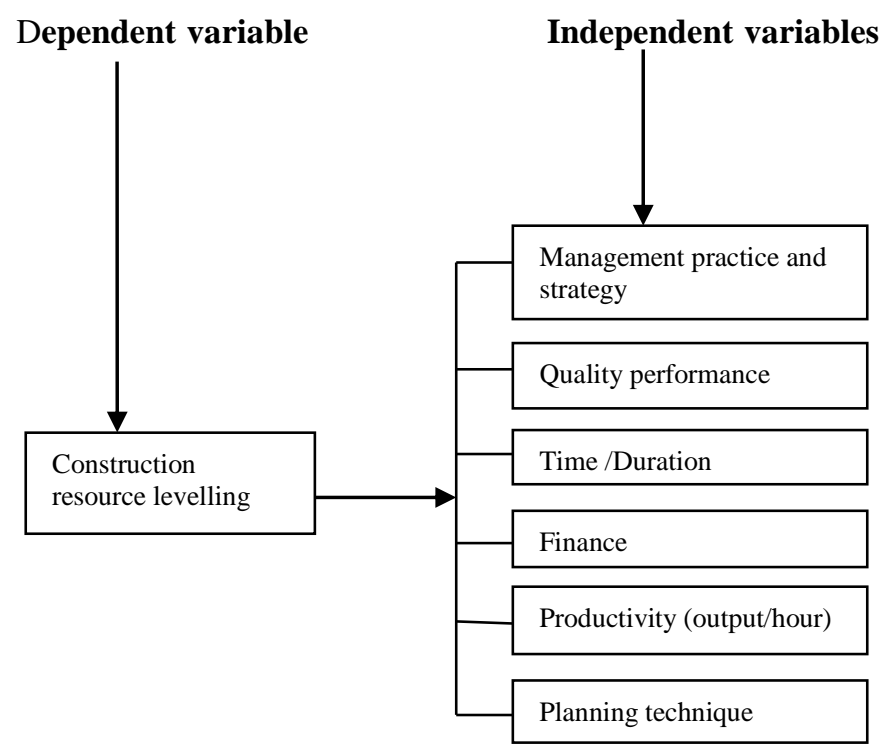

Fig. 1. Conceptual framework

Source: Author, 2017 
The above relationship of resource levelling in the conceptual framework can be stated statistically in Multiple Regression Analysis (MRA) as:

$$
\text { CRL = Fo }(\mathrm{Mp}, \mathrm{Cp}, \mathrm{Tm}, \mathrm{Fn}, \mathrm{Pb}, \mathrm{Pt})
$$

Where

$\mathrm{CRL}=$ Construction Resource Levelling and the following independent variables

$$
\begin{aligned}
& \mathrm{Mp}=\text { Management practice } \\
& \mathrm{Cp}=\text { Complexity of project } \\
& \mathrm{Tm}=\text { Time } \\
& \mathrm{Fn}=\text { Finance } \\
& \mathrm{Pd}=\text { Productivity } \\
& \mathrm{Pt}=\text { Construction planning technique }
\end{aligned}
$$

Fo means 'function of' (influenced by).

\section{METHODOLOGY}

\section{A. Research Design}

The research design used in this study was of the mixed method (Creswell, 2014). The data collection proceeded in two phases with quantitative data collection and analysis in the first phase, and then followed up with qualitative interviews which helped to explain and confirm or answer the question of 'how and why' in the survey responses.

\section{B. Research Method.}

Primary data was gathered directly from the site through questionnaires, interview schedules, direct observation and documentary analysis in Nairobi County. The questionnaires comprised of both structured and open ended questions and were self-administered to contractors and their top technical staff on live construction sites so as to get their general view or perception of the required information. Interview schedules were used to confirm the information obtain through face-to- face encounter with contractors and their senior technical staff.

\section{Research tools}

The study embraced the use of both quantitative and qualitative approaches to collect both primary and secondary data using a variety of instruments Questionnaires were used as the main instrument for collecting quantitative data and were complimented with interviews from targeted respondents. Observation list, time study forms and multiple activity process charts were used for direct recording of observation of studied activities on site. On the other hand since all the information could not be obtained from the field, the researcher supplemented information using secondary data from previous project records, internet, journals articles, conference papers and magazines among others

\section{Sampling Method}

For the quantitative phase of data collection, Stratified sampling method was used for picking respondents as a clear framework for categories of NCA (NCA3 to NCA6) contractors was readily available from the register of contractors (GOK, 2016). Tromp (2011) argues that for the purpose of generalization of the results findings, a researcher would need a minimum of 30 subjects in each group for corelational and descriptive research. A total of 104 of them participated from the initially targeted 143 respondents. Purposive sampling method was used in the second phase of qualitative data collection through interviews. Further, construction projects that had insitu concrete works in progress were considered to have the desired information and were included in the sample in the second phase

\section{E. Data analysis Method}

Data from questionnaires, observation checklist and interview schedules were coded to assist in analysis. Responses from closed ended questions were assigned numerical values and analyzed quantitatively using mean item score and percentages whereas the open ended questions were analyzed qualitatively.

For closed ended questions, the analysis involved the use of mean item score, frequency count and ranking generated through use Relative Importance Index (RII) and statistical package for social sciences (SPSS) version 21 to generate tables, pie charts the data from the field survey Microsoft office excel 10 was also used to generate other charts and graphs for evaluation of impacts on resource levelling practices and performance by construction firms' in Kenya.

The RII of the identified performance factors were computed using a designed 5-point likert scale as follows:

$$
R I I=\frac{\sum W}{A X N}
$$

Where:

$\mathbf{W}=$ the weight given to each factor by the respondents on a likert scale of 1 to 5

$$
\begin{aligned}
& \mathbf{A}=\text { the highest weight (5) } \\
& \mathbf{N}=\text { the total number of respondents }
\end{aligned}
$$

\section{F. Data Validity and Reliability}

To check on data validity the study relied on interviews with senior technical personnel in the contractor's organization and use of an inspection checklist. The reliability was enhanced by adopting a larger population sample of the 143 target population. In this study $73 \%$ of the target population was considered which translated to 104 respondents out of the 143 respondents targeted for the study. Reliability is defined as a measure of the degree to which a research instrument yields consistent results or data after repeated trials (Mugenda).

According to Creswell (2014), there are four different methods of assessing reliability in data and these four are: test-retested, equivalent form, split-half and internal consistency. In this study, the internal consistency method was used. Cronbach's alpha which is the most common reliability coefficient method for estimating internal 
consistency was used to test the questionnaire reliability. Cronbach's alpha (a) was therefore used to test the questionnaire construct consistency and level of random error. Cronbach's alpha reliability coefficient normally ranges between 0.0 and 1.0. The closer Cronbach's alpha coefficient is to 1.0 the greater the internal consistency of the items in the scale (Creswell, 2014). The Cronbach's Coefficient Alpha was computed to determine how items correlate among themselves using the following standardized formula:

$$
\alpha=\frac{N \cdot c}{\bar{v}+(N-1) \bar{c}}
$$

Where $\boldsymbol{\alpha}=$ Cronbach's Coefficient Alpha

$\mathbf{N}=$ the number of items considered

$\overline{\mathbf{c}}=$ the mean of the inter-item covariance among the items

$$
\overline{\mathbf{v}}=\text { the average variance. }
$$

George and Marllery (2008) provided a commonly accepted rule of thumb for describing internal consistency using Cronbach's alpha as indicated in Table 1:

Table 1: Cronbach's Consistency Alpha

\begin{tabular}{|c|c|}
\hline Cronbach's Coefficient Alpha & Internal Consistency Remarks \\
\hline$\alpha \geq 0.9$ & Excellent \\
\hline $0.7 \leq \alpha<0.9$ & Good \\
\hline $0.6 \leq \alpha<0.7$ & Acceptable \\
\hline $0.5 \leq \alpha<0.6$ & Poor \\
\hline$\alpha<0.5$ & Unacceptable \\
\hline
\end{tabular}

\section{Source: Adopted from George D. \& P. Marllery, (2008)}

The Cronbach's alpha coefficient was calculated using SPSS version 21 and the subsequent relationship between the individual items and the overall scale was examined. Table 2 shows a summary of the results obtained from the study survey for the questions on the 'evaluation of construction project performance factors'. The results from the study are in the range of ' $0.7 \leq \alpha<0.9$ ' which are considered to be 'good' Cronbach's alpha values (Marlley, 2008).

Table 2: Cronbach's Alpha results

\begin{tabular}{|l|l|c|c|}
\hline $\begin{array}{l}\text { Research instruments } \\
\text { Question }\end{array}$ & $\begin{array}{l}\text { Evaluation with respect } \\
\text { to the following actors: }\end{array}$ & $\begin{array}{c}\text { Number } \\
\text { of items }\end{array}$ & $\begin{array}{c}\text { Cronbach's } \\
\text { Alpha }\end{array}$ \\
\hline Sec B Part I, Q6 & $\begin{array}{l}\text { Construction project } \\
\text { performance }\end{array}$ & 14 & 0.749 \\
\hline Sec B Part I, Q7 & $\begin{array}{l}\text { Construction project } \\
\text { implementation practice }\end{array}$ & 14 & 0.784 \\
\hline $\begin{array}{l}\text { Sec B Part III, } \\
\text { Table VII }\end{array}$ & $\begin{array}{l}\text { Performance } \\
\text { measurement indicators }\end{array}$ & $80(10 * 8)$ & 0.894 \\
\hline
\end{tabular}

Source: Author, 2018

\section{FINDINGS}

A. Evaluation of efectiveness of resource levelling management tools on performance and implementation practice with regard to resource utilization

The fourteen critical resource levelling management tools which contribute to the enhancement of the performance of construction firms were identified from the literature search and were evaluated by the respondents in accordance with their level of significance on performance on construction firms. The tools were: skills and training in management, construction planning, uniqueness and complexity of the project, duration control mechanism, financial control, productivity, economic environment, matching of resources, resource prediction, resource recruitment, resource control, decision making, site organization and strategizing work. Tables 3 and 4 presents the findings from the respondents' evaluation on the rank order of the fourteen important assessment tools for resource levelling management practice on performance of construction firms with regard to resource utilization. Table 5 gives the overall summary of the ranking obtained from Tables 3 ad 4 .

Table 3: RII - Evaluation on the performance of construction

\begin{tabular}{|c|c|c|c|c|c|c|c|c|c|}
\hline \multirow{3}{*}{ Tools } & \multicolumn{5}{|c|}{ Likert Scale } & \multicolumn{4}{|c|}{ Overall } \\
\hline & 1 & 2 & 3 & 4 & 5 & \multirow[t]{2}{*}{$\Sigma w$} & $\mathrm{~A}$ & \multirow[t]{2}{*}{ RII } & \multirow{2}{*}{$\begin{array}{l}\mathrm{Ra} \\
\mathrm{nk}\end{array}$} \\
\hline & \multicolumn{5}{|c|}{ Frequency of responses } & & $\begin{array}{c}\mathrm{X} \\
\mathrm{N}\end{array}$ & & \\
\hline $\begin{array}{l}\text { Construction } \\
\text { planning }\end{array}$ & 0 & 0 & 6 & 22 & 76 & 486 & 520 & 0.935 & 1 \\
\hline $\begin{array}{l}\text { Financial } \\
\text { control }\end{array}$ & 0 & 0 & 11 & 29 & 64 & 469 & 520 & 0.902 & 2 \\
\hline $\begin{array}{l}\text { Resource } \\
\text { control }\end{array}$ & 0 & 10 & 9 & 35 & 50 & 437 & 520 & 0.840 & 3 \\
\hline $\begin{array}{l}\text { Strategizing } \\
\text { work }\end{array}$ & 0 & 6 & 18 & 31 & 49 & 435 & 520 & 0.837 & 4 \\
\hline $\begin{array}{l}\text { Decision } \\
\text { making }\end{array}$ & 0 & 3 & 25 & 32 & 44 & 429 & 520 & 0.825 & 5 \\
\hline $\begin{array}{l}\text { Skills and } \\
\text { training in } \\
\text { management }\end{array}$ & 2 & 9 & 19 & 26 & 48 & 421 & 520 & 0.810 & 6 \\
\hline $\begin{array}{l}\text { Matching of } \\
\text { resources }\end{array}$ & 0 & 9 & 27 & 36 & 32 & 403 & 520 & 0.775 & 7 \\
\hline $\begin{array}{l}\text { Site } \\
\text { organization }\end{array}$ & 3 & 12 & 17 & 49 & 23 & 389 & 520 & 0.748 & 8 \\
\hline $\begin{array}{l}\text { Duration } \\
\text { control } \\
\text { mechanism }\end{array}$ & 0 & 14 & 34 & 40 & 16 & 370 & 520 & 0.712 & 9 \\
\hline $\begin{array}{l}\text { Resource } \\
\text { recruitment }\end{array}$ & 0 & 22 & 38 & 27 & 17 & 351 & 520 & 0.675 & 10 \\
\hline $\begin{array}{l}\text { Resource } \\
\text { prediction }\end{array}$ & 5 & 9 & 54 & 22 & 14 & 343 & 520 & 0.660 & 11 \\
\hline $\begin{array}{l}\text { Uniqueness } \\
\text { and } \\
\text { complexity }\end{array}$ & 7 & 24 & 27 & 34 & 14 & 342 & 520 & 0.658 & 12 \\
\hline $\begin{array}{l}\text { Production } \\
\text { output } \\
\text { prediction }\end{array}$ & 0 & 15 & 35 & 28 & 16 & 327 & 520 & 0.629 & 13 \\
\hline $\begin{array}{l}\text { Economic } \\
\text { environment }\end{array}$ & 10 & 25 & 36 & 25 & 8 & 308 & 520 & 0.592 & 14 \\
\hline
\end{tabular}
firms

Source: Author, 2018 
Table 4: RII - Evaluation on construction project implementation practice

\begin{tabular}{|c|c|c|c|c|c|c|c|c|c|}
\hline \multirow{3}{*}{ Tools } & \multicolumn{5}{|c|}{ Likert Scale } & \multicolumn{4}{|c|}{ Overall } \\
\hline & 1 & 2 & 3 & 4 & 5 & \multirow[t]{2}{*}{$\Sigma \mathrm{w}$} & \multirow{2}{*}{$\begin{array}{l}\mathrm{A} \\
\mathrm{X} \\
\mathrm{N}\end{array}$} & \multirow[t]{2}{*}{ RII } & \multirow{2}{*}{$\begin{array}{l}\mathrm{Ra} \\
\mathrm{nk}\end{array}$} \\
\hline & \multicolumn{5}{|c|}{ Frequency of responses } & & & & \\
\hline $\begin{array}{l}\text { Construction } \\
\text { planning }\end{array}$ & 0 & 3 & 3 & 27 & 71 & 478 & 520 & 0.919 & 1 \\
\hline $\begin{array}{l}\text { Financial } \\
\text { control }\end{array}$ & 0 & 0 & 15 & 38 & 51 & 452 & 520 & 0.869 & 2 \\
\hline $\begin{array}{l}\text { Resource } \\
\text { control }\end{array}$ & 0 & 3 & 11 & 38 & 52 & 451 & 520 & 0.867 & 3 \\
\hline $\begin{array}{l}\text { Decision } \\
\text { making }\end{array}$ & 0 & 9 & 8 & 28 & 59 & 449 & 520 & 0.863 & 4 \\
\hline $\begin{array}{l}\text { Strategizing } \\
\text { work }\end{array}$ & 0 & 9 & 16 & 23 & 56 & 438 & 520 & 0.842 & 5 \\
\hline $\begin{array}{l}\text { Skills and } \\
\text { training in } \\
\text { management }\end{array}$ & 2 & 10 & 7 & 32 & 53 & 436 & 520 & 0.838 & 6 \\
\hline $\begin{array}{l}\text { Site } \\
\text { organization }\end{array}$ & 3 & 5 & 26 & 38 & 32 & 403 & 520 & 0.775 & 7 \\
\hline $\begin{array}{l}\text { Matching of } \\
\text { resources }\end{array}$ & 0 & 6 & 30 & 44 & 24 & 398 & 520 & 0.765 & 8 \\
\hline $\begin{array}{l}\text { Duration } \\
\text { control } \\
\text { mechanism }\end{array}$ & 3 & 7 & 28 & 39 & 27 & 392 & 520 & 0.754 & 9 \\
\hline $\begin{array}{l}\text { Production } \\
\text { output } \\
\text { prediction }\end{array}$ & 0 & 18 & 18 & 45 & 23 & 385 & 520 & 0.740 & 10 \\
\hline $\begin{array}{l}\text { Resource } \\
\text { recruitment }\end{array}$ & 0 & 10 & 34 & 40 & 20 & 382 & 520 & 0.735 & 11 \\
\hline $\begin{array}{l}\text { Resource } \\
\text { prediction }\end{array}$ & 2 & 14 & 28 & 41 & 19 & 373 & 520 & 0.717 & 12 \\
\hline $\begin{array}{l}\text { Uniqueness \& } \\
\text { complexity }\end{array}$ & 5 & 14 & 24 & 38 & 22 & 367 & 520 & 0.706 & 13 \\
\hline $\begin{array}{l}\text { Economic } \\
\text { environment }\end{array}$ & 7 & 19 & 36 & 36 & 6 & 327 & 520 & 0.629 & 14 \\
\hline
\end{tabular}

Source: Field Survey, 2018

Table 5: Ranking of management tools which contribute to the enhancement of construction project performance and implementation practice using RII

\begin{tabular}{|l|c|c|c|c|c|c|}
\hline \multirow{2}{*}{\multicolumn{1}{c|}{ Tools }} & \multicolumn{2}{|c|}{ Overall } & \multicolumn{2}{c|}{ Performance } & \multicolumn{2}{c|}{$\begin{array}{c}\text { Implementation } \\
\text { practice }\end{array}$} \\
\cline { 2 - 7 } & RII & $\begin{array}{c}\text { Ra } \\
\text { nk }\end{array}$ & RII & $\begin{array}{c}\text { Ra } \\
\text { nk }\end{array}$ & RII & Rank \\
\hline Construction planning & 0.919 & 1 & 0.935 & 1 & 0.927 & 1 \\
\hline $\begin{array}{l}\text { Financial control } \\
\text { (Budget allocation) }\end{array}$ & 0.869 & 2 & 0.902 & 2 & 0.886 & 2 \\
\hline Resource control & 0.867 & 3 & 0.840 & 3 & 0.854 & 3 \\
\hline Decision making & 0.863 & 4 & 0.825 & 3 & 0.844 & 4 \\
\hline Strategizing work & 0.842 & 5 & 0.837 & 4 & 0.840 & 5 \\
\hline $\begin{array}{l}\text { Skills and training in } \\
\text { management }\end{array}$ & 0.838 & 6 & 0.810 & 6 & 0.824 & 6 \\
\hline Site organization & 0.775 & 7 & 0.748 & 8 & 0.812 & 7 \\
\hline Matching of resources & 0.765 & 8 & 0.775 & 7 & 0.770 & 8 \\
\hline $\begin{array}{l}\text { Duration control } \\
\text { mechanism }\end{array}$ & 0.754 & 9 & 0.712 & 9 & 0.733 & 9 \\
\hline Resource recruitment & 0.735 & 11 & 0.675 & 10 & 0.705 & 10 \\
\hline Resource prediction & 0.717 & 12 & 0.660 & 11 & 0.689 & 11 \\
\hline $\begin{array}{l}\text { Production output } \\
\text { prediction }\end{array}$ & 0.740 & 10 & 0.629 & 13 & 0.685 & 12 \\
\hline $\begin{array}{l}\text { Uniqueness and } \\
\text { complexity }\end{array}$ & 0.706 & 13 & 0.658 & 12 & 0.682 & 13 \\
\hline $\begin{array}{l}\text { Economic } \\
\text { environment }\end{array}$ & 0.629 & 14 & 0.592 & 14 & 0.611 & 14 \\
\hline
\end{tabular}

The findings of this study revealed that construction planning was the most important tool that contributes to the enhancement of construction project performance in the construction industry. The results from this study is in agreement with Muchungu (2012) who pointed out that all resources (people, materials, plant, time, finance and technology) have to be aligned to the construction programme if performance has to be improved. Proper planning will make the labourforce work more systematically and finance will be available on time. More skill and experience among the managers will enhance construction project planning. In addition, at the times set in the programme, other resources like materials and plant will be delivered on time. From the above results, the authors recommend that construction firms should invest adequately in the training of supervisors in the management tools of construction planning, financial control and resource control if improvement in performance is to be enhanced.

\section{B. Prioritization of resource levelling management tools for project performance evaluation by construction firms.}

Eight key project performance characteristics which are likely to influence the overall project performance of construction firms' in Kenya was evaluated by the respondents in accordance with respect to the relative importance that each of the characteristics would affect the overall performance on site with regard to resource utilization. The characteristics were: project time, project cost and profitability, quality performance, adherence to construction programmes, productivity levels required, project size, project complexity and control tools. Table 6 presents the findings from the respondents' evaluation on the rank order of the most significant project characteristics which are likely to influence the overall project performance of construction firms in Kenya.

Table 6 Cronbach's Alpha for Prioritized Project performance Evaluation Indicators

\begin{tabular}{|l|c|c|c|c|}
\hline $\begin{array}{l}\text { Performance evaluation } \\
\text { tools }\end{array}$ & $\begin{array}{c}\text { No. of } \\
\text { items / } \\
\text { resources }\end{array}$ & $\begin{array}{c}\text { Respondents } \\
\text { (No.) }\end{array}$ & $\begin{array}{c}\text { Significance } \\
\text { Scale } \\
(\%)\end{array}$ & $\begin{array}{c}\text { Ra } \\
\text { nk }\end{array}$ \\
\hline $\begin{array}{l}\text { Project cost(complete within } \\
\text { budget) /profitability }\end{array}$ & 10 & 104 & 82.8 & 1 \\
\hline $\begin{array}{l}\text { Project time (complete on } \\
\text { time) }\end{array}$ & 10 & 104 & 81.6 & 2 \\
\hline $\begin{array}{l}\text { Quality of performance } \\
\text { (achieve specifications) }\end{array}$ & 10 & 104 & 76.8 & 3 \\
\hline Productivity levels required & 10 & 104 & 74.9 & 4 \\
\hline $\begin{array}{l}\text { Adherence to construction } \\
\text { programmes }\end{array}$ & 10 & 104 & 73.8 & 5 \\
\hline Project control tools & 10 & 104 & 70.8 & 6 \\
\hline Project size & 10 & 104 & 70.7 & 7 \\
\hline Project complexity & 10 & 104 & 70.3 & 8 \\
\hline
\end{tabular}

Source: Author, 2018 
The findings of this study established that project cost (completing within budget) was the most significant project evaluation tool that influence the overall project performance of construction firms in Kenya with a computed average percentage score of $82.8 \%$. The success of all construction activities and resources on site are tied to the budget. The cost was followed closely by project time and quality performance with computed average of $81.6 \%$ and $76.8 \%$ respectively. The findings from the study confirmed the 'iron triangle' position of Atkinson's (1999) observation with respect to the most important and significant measure of project performance in construction firms.

\section{CONCLUSION}

The findings from the study revealed three principal management tools that impact towards the enhancement of construction firms' performance in Kenya namely: construction planning, financial control and resource control. It was found that these three tools are associated with a number of key project factors for the measurement of effective performance by construction firms, in particular, project cost, project time and quality Performance. According to the overall analysis from the study, project cost/profitability was the most critical factor for evaluation of effective performance by construction firms. From the contractors' perspective, it is project profitability making that is the most critical factor for the measurement of effective performance (Inuwa, 2014).

This paper has provided a prioritized list of relative importance for project performance evaluation which can serve as a tool to enhance construction project performance. It will facilitate the top management in construction firms in strategic decision making, enhance financial stability, improve efficiency and effectiveness in resource utilization, and delivery of quality projects to clients on time. The study recommends that further research should be undertaken on the development of a prioritized project performance evaluation model' for the construction firms' in Kenya.

\section{REFERENCES}

[1] Chitkara, K. (2012). Construction project management planning scheduling and controlling. New Delhi: Tata McGraw-Hill.

[2] Creswell, J.W. (2014). Research designs: Qualitative and mixed approaches $\left(4^{\text {th }}\right.$ Ed. $)$, London, SAGE

[3] El-Rayes, K., \& Jun, D. H. (2009). Optimizing Resource Levelling in Construction Projects, Journal for Construction Engineering and Management, 135(11), 1172-1180.

[4] Forster, G. (2014). Construction site studies production, administration and personnel. London and New York: Published by Longman.

[5] Galloway, P. D. (2006). "Survey of the construction industry relative to the use of CPM scheduling for construction projects." Journal of Construction Engineering and Management, ASCE, 132(7), 697-711.

[6] Gichunge, H. (2000). Risk Management in The Building Industry in Kenya: Unpublished PhD Thesis. University of Nairobi, Nairobi.

[7] GoK. (2016). NCA, Register of Contractor. Nairobi: Government Press.

[8] Gwaya, A.O. (2015). Development of a project management evaluation model for the construction industry in Kenya. Nairobi: Published $\mathrm{PhD}$ Thesis, JKUAT.

[9] Harington, R. (2007). Mitchell's Building construction Structure and Fabric Part 2. London: Prentice Hall.
[10] Harris, F. \& McCaffer, R. (2013).Modern Construction managemen ( $7^{\text {th }}$ Ed.).. London. Black Science Ltd.

[11] ILO. (1996-2016). Introduction to Work Study. GENEVA: Publications of international labour Office.

[12] Inuwa I. I. (2014). Project planning in construction procurement: the case of Nigerian indigenous contractors. Nairobi: Published PhD Thesis, JKUAT.

[13] KNBS (2016). Kenya National Bureau of statistics (KNBS), Nairobi: Government press.

[14] Masu, S. (2006). An Investigation into the causes and impact of Resource mix practices the performance of construction fitms in Kenya. Nairobi: Unpublished PhD Thesis, University of Nairobi.

[15] Mbiti, T. K. (2008). A System Dynamics Model of Construction Output in Kenya, PhD Thesis, School of Property and Construction Project Management. Melbourne, Australia: RMIT University.

[16] Muchungu, P. (2012). The contribution of human factor in the performance of construction firms in Kenya. Nairobi: Unpublished $\mathrm{PhD}$ Thesis, University of Nairobi.

[17] Ofori, G. (2001), "Indicators for Measuring Construction Industry Development in Developing Countries", Building Research \& Information, Vol. 29, No. 1, pp 40-50

[18] PMI. (2015). A guide to the Project Management Body of Knowledge: PMBOK Guide. New York: Project Management Institute.

[19] Talukhaba, A. A. (1999). An investigation into The Factors Causing Construction Project Delays in Kenya. Case Study of High-rise Building Projects in Nairobi. Unpublished PhD. Thesis. University of Nairobi, Nairobi, Kenya.

[20] Tromp, K. (2011). Proposal and Thesis writing an introduction Nairobi: Pauline publications Africa.

[21] Wanyona, G. (2005). Risk management in the cost planning and contro of building projects. The case of Quantity Surveying profession in Kenya. Unpublished PhD Thesis. University of Cape Town., Cape Town, South Africa

\section{AUTHORS PROFILE}

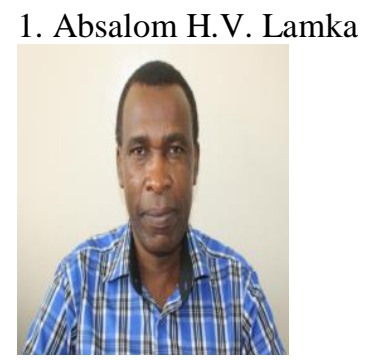

A. Academic Professional Qualification

$\mathrm{PhD}$ (Constn Project Mgt - candidate), $T U-K$; Master of Constn Project Mgt (JKUAT); B.Phil. Constn Mgt $(U o N)$; Cert Constn Engineering (Polytechnic University, Japan); H/Dip (Constn); Dip. (Bld \& Civil Engineering); M.A.A.K. (CPM-3889); MIET (M/No.1007)

\section{B. Specialization}

Construction Project Management, Construction Contract Documentation, Measurements of building, Measurements of building works, Civil Engineering Measurement and Construction Productivity 


\section{Prof. QS. Sylvester Munguti Masu}

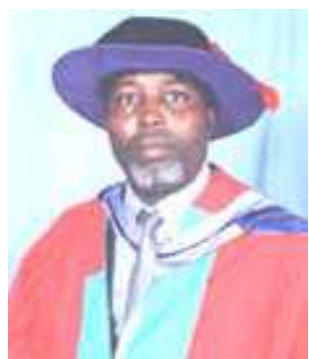

A. Academic Professional Qualification $\mathrm{PhD}$ (Constn. Mgt.) UoN; M.A (Bldg. Mgt) UoN; B.A. (Bldg. Econs.) Hons, UoN; M.A.A.K. (Q.S); A.C.I. Arb; F.I.Q.S.K; Registered Q.S, (Q182). F.I.C.P.M (K)

\section{B. Specialization}

Construction Project Management, Construction Contract Documentation, Arbitration and Dispute Resolution, Procurement Management and General Quantity Surveying.

\section{Dr. Wanyona Githae}

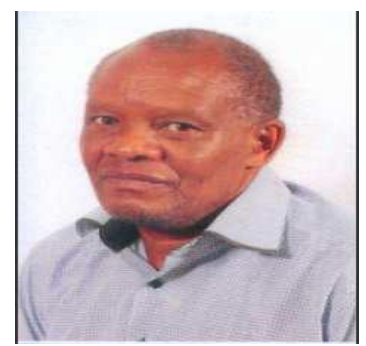

\section{A. Academic Professional Qualification}

$\mathrm{PhD}$ (UCT, South Africa); M. Engineering (Kyoto University, Japan); B.A (Bldg. Econs) UoN; M.A.A.K. (QS-201); Registered Q.S, (CISQK-271).

\section{B. Specialization}

Construction Project Management, Construction Contract Documentation, Project Risk Management, Project Procurement Systems and General Quantity Surveying. 